\title{
PENGARUH MOTIVASI INTRINSIK, PENGETAHUAN KEWIRAUSAHAAN, DAN KEPRIBADIAN TERHADAP MINAT BERWIRAUSAHA PADA SISWA SMKN 12 SURABAYA
}

\author{
Asti Iswandari *
}

\begin{abstract}
The purposes of this study were to determine the effects of intrinsic motivation, entrepreneurial knowledge, and personality on student interest in entrepreneurship. Population of this study were students from grade XII of the 12th State Vocational School of Surabaya, for academic year 2012-2013 with total of 578 students. 236 samples were taken using proportional random sampling. Data were collected by questionnaires and documentations. This study was using quantitative analysis with multiple linear regression. The results showed that there are simultaneous effects between intrinsic motivation, entrepreneurial knowledge, and personality on student interest in entrepreneurship. Partially, there is an effect of intrinsic motivation and personality on student interest in entrepreneurship, whereas there is no effect of entrepreneurial knowledge on student interest in entrepreneurship.
\end{abstract}

Keywords: intrinsic motivation, entrepreneurial knowledge, personality, student interest in entrepreneurship.

\section{PENDAHULUAN}

Setiap siswa Sekolah Menengah Kejuruan (SMK) pasca menyelesaikan pendidikan mereka, tentu mempunyai harapan bisa menggunakan ilmu pengetahuan, keterampilan, dan keahlian yang telah didapat selama di bangku sekolah untuk terjun ke masyarakat melalui berbagai pilihan profesi seperti : menjadi karyawan/pegawai baik swasta ataupun negeri, melanjutkan pendidikan ke Perguruan Tinggi, menjadi pengangguran intelektual, dan membuka usaha sendiri (berwirausaha). Pilihan terakhir inilah yang oleh pemerintah berusaha untuk dikembangkan.

Sekolah berperan besar dan strategis untuk mengembangkan kewirausahaan di kalangan siswa SMK sekaligus mengubah, sikap siswa dari mencari kerja menjadi pencipta lapangan kerja (wirausaha). Upaya ini perlu dilakukan mengingat orientasi masyarakat kita masih memilih pekerjaan yang memberikan jaminan seperti Pegawai Negeri Sipil (PNS) atau pekerja (buruh), tanpa menyadari bahwa ketersediaan lapangan kerja masih terbatas, tidak kompetennya lulusan dengan tuntutan dunia kerja, dan sebagainya. Minat untuk berwirausaha tanpaknya hanya merupakan pilihan terakhir jika meraka gagal dalam persaingan mendapatkan pekerjaan.

Fenomena yang ada pada SMKN 12 berkaitan dengan minat berwirausaha dapat dilihat pada tabel di bawah ini:

*) Guru SMKN 12 Surabaya 
Tabel 1. Rekapitulasi Penelusuran Tamatan Siswa SMKN 12 Surabaya

\begin{tabular}{|l|c|c|c|c|}
\hline Tahun Pelajaran & $\begin{array}{c}\text { Melanjutkan } \\
\text { Pendidikan (\%) }\end{array}$ & Bekerja (\%) & $\begin{array}{c}\text { Berwirausaha } \\
(\%)\end{array}$ & $\begin{array}{c}\text { Tidak Bekerja } \\
(\%)\end{array}$ \\
\hline $2006-2007$ & 17 & 73 & 1 & 9 \\
\hline $2007-2008$ & 38,16 & 58,33 & 1,69 & 2,08 \\
\hline $2008-2009$ & 33,02 & 59,24 & 0,29 & 2,36 \\
\hline $2009-2010$ & 27,57 & 65,39 & 0,41 & 6,61 \\
\hline $2011-2012$ & 23,82 & 66,11 & 0,70 & 9,35 \\
\hline
\end{tabular}

Sumber : Humas SMKN 12 Surabaya

Berdasarkan Fenomena di atas dapat dilihat bahwa jumlah lulusan SMKN 12 Surabaya yang memilih profesi sebagai wirausaha kurang dari $2 \%$. Ini jauh dari standart ideal yang diharapkan yaitu sedikitnya $2 \%$ dari jumlah lulusan. Hal ini sesuai dengan yang dikemukakan oleh David McCleland (dalam Ciputra,2011:14) sebuah negara baru akan makmur kalau sedikitnya 2\% dari penduduknya jadi entrepreneur. Fakta dilapangan yang menunjukkan kecilnya persentase siswa kelas XII SMKN 12 Surabaya yang memilih berwirausaha disebabkan karena rendahnya minat siswa dalam berwirausaha

Rendahnya minat siswa untuk berwirausaha juga dikarenakan pola pikir mereka mengenai dunia wirausaha, menurut mereka terjun ke dunia bisnis bukanlah pilihan karir yang tepat. Mereka berpikir bahwa untuk berwirausaha mereka akan dihadapkan pada situasi yang tidak pasti, dibutuhkan modal yang besar, penuh dengan tantangan, penghasilannya tidak tetap, banyak resikonya sehingga mereka takut gagal.Padahal menurut Shcumpeter (dalam Wibowo,2011:19) faktor yang paling menentukan dalam pertumbuhan ekonomi suatu negara adalah pengusaha yang mampu melakukan inovasi dan kreativitas .Wirausaha yang tangguh telah terbukti mampu meningkatkan kesejahteraan masyarakat secara menyeluruh. Wirausaha melalui usahanya telah mampu menyerap angkatan kerja, mengolah kekayaan alam, dan mendorong pertumbuhan perekonomian negara.

Shaleh dan Wahab (2004:262) menerangkan bahwa minat adalah sebagai"suatu kecenderungan untuk memberikan perhatian dan bertindak terhadap orang lain, aktivitas atau situasi yang menjadi objek dari minat tersebut dengan disertai perasaan senang" . Berbeda halnya dengan apa yang dikemukakan Djaali (2011:121) yang mengemukakan bahwa "minat adalah rasa lebih suka dan rasa ketertarikan pada suatu hal atau aktivitas, tanpa ada yang menyuruh".

Minat siswa untuk berwirausaha tidak bisa timbul begitu saja tanpa ada faktor-faktor yang mendukungnya. Menurut McClelland (dalam Utami, 2007:21) ada tiga faktor intern yang mempengaruhi minat seseorang dalam berwirausaha yaitu motivasi, pengalaman atau pengetahuan, dan kepribadian.

Motivasi sebagai salah satu faktor penting yang dapat mendorong keberanian seseorang untuk berwirausaha sangat perlu ditubuhkan dalam diri siswa khususya pada siswa kelas XII SMKN 12 Surabaya. Motivasi yang dimaksudkan disini adalah motivasi intrinsik siswa, yaitu motivasi yang timbul dalam diri individu itu sendiri, mengingat motivasi ekstrinsik yaitu motivasi yang timbul sebagai akibat pengaruh dari luar yaitu dalam hal ini dari sekolah maupun guru telah coba diberikan kepada siswa. 
Menurut Juwono (dalam Djaali,2011:104) motivasi diperlukan bagi rein-forcement (stimulus yang memperkuat dan mempertahankan tingkah laku yang dikehendaki). Motivasi menyebabkan timbulnya berbagai tingkah laku, dimana salah satu di antaranya mungkin dapat merupakan tingkah laku yang dikehendaki. Untuk menjadi seorang wirausaha dibutuhkan antara lain sikap kemandirian dan keinginan untuk selalu menghasilkan sesuatu yang terbaik (berprestasi).

Selain motivasi intrinsik, minat seseorang dalam berwirausaha juga dipengaruhi oleh pengetahuan tentang kewirausahaan itu sendiri. Seorang wirausahawan tidak akan berhasil apabila tidak memiliki pengetahuan, kemampuan, dan kemauan. Hal tersebut sesuai yang diungkapkan Suryana (2009:82) bahwa untuk menjadi wirausaha yang berhasil, persyaratan utama yang harus dimiliki adalah memiliki jiwa dan watak kewirausahaan. Jiwa dan watak kewirausahaan tersebut dipengaruhi oleh keterampilan, kemampuan, atau kompetensi.Kompetensi itu sendiri ditentukan oleh pengetahuan dan pengalaman usaha.

Faktor lain yang berpengaruh terhadap minat siswa dalam berwirausaha adalah kepribadian. Menurut Agustiani (dalam Fitriani,2009:24). Kepribadian seseorang tidak sama persis sama dengan kepribadian orang lain. Dengan kepribadian yang dimiliki oleh seseorang dia dapat memikat orang lain, orang menjadi simpati padanya, orang tertarik dengan pembicarannya, orang terkesima olehnya.Kepribadian individu sangat berpengaruh terhadap keberhasilan usaha. Kepribadian yang matang untuk dapat menghadapi masalah dengan pikiran terbuka adalah sikap yang baik bagi seorang wirausaha.

Beberapa temuan peneliti tentang minat berwirausaha diantaranya Mahesa dan Rahardja (2012) yang menyimpulkan bahwa faktor-faktor motivasi yaitu toleransi akan resiko, keberhasilan diri dalam berwirausaha, dan keinginan untuk bebas bekerja memiliki pengaruh positif terhadap minat berwirausaha. Segal, Borgia, dan Schoenfeld (2005) menyimpulkan bahwa faktor motivasi:toleransi akan resiko, keberhasilan diri, dan keinginan untuk merasakan kebebasan mempengaruhi minat berwirausaha.Aprilianty (2012) potensi kepribadian wirausaha, pengetahuan kewirausahaan, dan lingkungan keluarga berpengaruh terhadap minat berwirausaha

Berdasarkan kajian diatas, maka rumusan hipotesis penelitian ini adalah sebagai berikut:

1. Diduga ada pengaruh signifikan motivasi instrinsik terhadap minat berwirauasaha.

2. Diduga ada pengaruh signifikan pengetahuan kewirausahaan terhadap minat berwirausaha.

3. Diduga ada pengaruh signifikan kepribadian terhadap minat berwirausaha.

4. Diduga ada pengaruh signifikan secara bersama-sama antara motivasi instrinsik, pengetahuan kewirausahaan, dan kepribadian terhadap minat berwirausaha.

\section{METODE PENELITIAN}

Pendekatan penelitian yang digunakan dalam penelitian ini adalah pendekatan kuantitatif Jenis penelitian yang digunakan adalah penelitian tingkat eksplanasi (level of explanation). Variabel yang digunakan pada penelitian ini adalah motivasi intrinsik (X1), pengetahuan kewirausahaan (X2), kepribadian (X3) dan minat berwirausaha (Y).

Populasi dalam penelitian ini adalah siswa kelas XII SMKN 12 Surabaya sebanyak 578 siswa.Jumlah sampel yang digunakan sebanyak 236 siswa. Sampel ditentukan den- 
gan menggukan rumus Slovin. Teknik pengambilan sampel yang akan digunakan adalah proporsional random sampling. Menurut Sugiyono (2008:120) Proporsional random sampling adalah pengambilan sampel dari populasi yang mempunyai strata secara proporsional dari setiap elemen populasi yang dijadikan sampel dan pengambilan sampel dilakukan secara random.

Data dikumpulkan menggunakan kuesioner dan dokumentasi. Dokumentasi digunakan untuk mengumpulkan data dari variabel pengetahuan dengan menggunakan nilai Ujian Akhir Semester (UAS). Sedangkan kuesioner digunakan untuk mengumpulkan data dari variabel motivasi intrinsik, kepribadian, dan minat berwirausaha. Kuesioner disusun berdasarkan variabel penelitian dan indikator penelitian dengan skala pengukuran instrument menggunakan skala likert. Berikut ini adalah indikator dari variabel motivasi intrinsik, kepribadian, dan minat berwirausaha:

1. Indikator motivasi intrinsik terdiri dari:
a. alasan keuangan
b. memperoleh kebebasan
c. alasan sosial
d. impian personal
e. kemandirian
f. alasan pelayanan
Sumber : Basrowi (2012) dan Suryana (2009)

2. Indikator kepribadian terdiri dari
a. percaya diri
b. kreatif
c. berani mengambil resiko
d. berorientasi pada tindakan
e. kepemimpinan
f. kerja keras
Sumber: Kemendiknas (2010), Suryana(2009), Basrowi (2011), Alma (2011)

3. Indikator minat berwirausaha terdiri dari:

a. pengungkapan:

1) keinginan untuk memilih dan menekuni profesi/aktivitas tertentu

2) rasa senang terhadap suatu aktivitas

b. tindakan

1) membuat pilihan aktivitas

Sumber : Super dan Crites (dalam Suryaman, 2006), Dew Ketut Sukardi (1998)

Teknik analisis menggunakan analisis regresi berganda dengan kriteria uji $\mathrm{F}$ dan uji t. Uji F digunakan untuk menguji signifikasi variabel motivasi intrinsik, pengetahuan kewirausahaan, dan kepribadian terhadap minat berwirausaha secara simultan. Sedangkan uji t digunakan untuk menguji signifikasi pengaruh motivasi intrinsik, pengetahuan kewirausahaan, dan kepribadian terhadap minat berwirausaha secara parsial. 


\section{HASIL PENELITIAN DAN PEMBAHASAN}

\section{Hasil Penelitian}

Model regresi yang diperoleh berdasarkan hasil penelitian, dapat dituliskan dalam bentuk persamaan regresi adalah sebagai berikut $\mathrm{MB}(\mathrm{Y})=9,436+0,111 \mathrm{MI}(\mathrm{X} 1)+0,007$ $\mathrm{PK}(\mathrm{X} 2)+0,270 \mathrm{Kp}(\mathrm{X} 3)+\mathrm{e}_{\mathrm{i}}$. Dari persamaan regresi tersebut, ketiga variabel bebas memiliki koefisien regresi dengan arah positif. Hal ini berarti semakin bagus motivasi intrinsik, pengetahuan kewirausahaan, dan kepribadian akan meningkatkan minat berwirausaha. Hasil uji F berdasarkan uji ANOVA atau uji statistik F, menunjukkan bahwa F hitung sebesar 32,712 dengan tingkat signifikan kurang dari 5\% yaitu 0,000, hal ini berarti variabel motivasi intrinsik, pengetahuan kewirausahaan, dan kepribadian secara simultan berpengaruh terhadap minat berwirausaha.

Besarnya koefisisen korelasi adalah 0,545 berarti hampir 29,7\% minat berwirausaha dipengaruhi oleh motivasi intrinsik, pengetahuan kewirausahaan, dan kepribadian. Sedangkan 70,3\% dipengaruhi oleh faktor-faktor lain diantaranya status dan pendapatan keluarga, tingkat pendidikan siswa, lingkungan.

Uji t digunakan untuk mengetahui pengaruh motivasi intrinsik, pengetahuan kewirausahaan, dan kepribadian secara parsial terhadap minat berwirausaha. Uji parsial menunjukkan variabel motivasi intrinsik memiliki nilai t hitung sebesar 4,191 dengan signifikansi 0,000 kurang dari 5\%. Hal ini berarti motivasi intrinsik secara parsial berpengaruh signifikan terhadap minat berwirausaha. variabel pengetahuan kewirausahan memiliki t hitung sebesar 0,098 dengan signifikansi 0,922 lebih dari 5\%. Hal ini berarti pengetahuan kewirausahaan secara parsial tidak berpengaruh signifikan terhadap minat berwirausaha; dan variabel kepribadian memiliki t hitung sebesar 6,990 dengan signifikansi 0,000 kurang dari 5\%.Hal ini berarti kepribadian secara parsial berpengaruh signifikan terhadap minat berwirausaha.

\section{Pembahasan}

1. Pengaruh Motivasi Intrinsik terhadap Minat Berwirausaha

Berdasarkan hasil penelitian mengenai pengaruh motivasi intrinsik terhadap minat berwirausaha menunjukkan bahwa motivasi berpengaruh terhadap minat berwirausaha . Implikasi dari penelitian ini adalah semakin baik motivasi intrinsik maka akan dapat meningkatkan minat berwirausaha.

Temuan ini yang menunjukkan bahwa motivasi intrinsik berpengaruh terhadap minat berwirausaha siswa seperti hasil penelitian dari Segal, Borgia,dan Schoenfeld (2005) dan Mahesa dan Rahardja (2011) bahwa keberhasilan diri, dan keinginan untuk merasakan kebebasan mempengaruhi minat berwirausaha.

Motivasi intrinsik adalah dorongan yang timbul dalam diri seseorang untuk melakukan sesuatu yang diinginkan.Motivasi intrinsik sangat penting karena dapat memberi kekuatan dan energy untuk melakukan beberapa hal yang ingin kita kerjakan, salah satu diantaranya adalah mendorong tumbuhnya minat untuk berwirausaha. Seseorang yang berminat untuk berwirausaha akan dipengaruhi oleh motif untuk berprestasi,yaitu keinginan untuk mencapai yang terbaik guna memperoleh kepuasan pribadi, didasari oleh adanya kebutuhan yang harus dipenuhi seperti keinginan untuk memperoleh penghasilan yang lebih besar, memperoleh kebebasan, keinginan untuk bisa membantu masyarakat (alasan sosial), meraih impian pribadinya, dan mandiri. Menurut Kurniawan (2012) den- 
gan adanya motivasi dalam diri, kita akan dengan mudah menjalankan apapun karena motivasi merupakan modal awal yang harus dipunyai dan dikembangkan oleh seseorang. Selain itu motivasi yang berasal dari dalam diri mempunyai kecenderungan yang lebih kuat serta tahan lama.

Motivasi intrinsik siswa SMKN 12 Surabaya sendiri untuk berwirausaha cukup tinggi hal ini bisa dilihat dari jawaban responden $76,30 \%$ menyatakan siswa berminat untuk berwirausaha karena termotivasi ingin membuka lapangan pekerjaan buat orang lain (alasan sosial) bukan semata-mata ingin mencari uang. Hal ini menunjukkan bahwa uang bukan satu-satunya alasan seseorang melakukan sesuatu. Sebagaimana yang disampaikan oleh Pink (2009) bahwa motivasi dasar manusia yang sebenarnya mendorong mereka untuk melakukan sesuatu bukanlah uang, tetapi ada 3 hal yaitu autonomi (kemandirian) yaitu keinginan untuk mengatur/mengelola hidup kita sendiri; mastery (penguasaan keahlian) yang berkaitan dengan naluri dasar manusia untuk terus menjadi lebih baik di hal-hal penting. Purpose (Tujuan) yaitu kebutuhan dasar kita untuk menjadi berguna buat sekitar entah itu komunitas ataupun masyarakat umum. Hal tersebut sesuai juga dengan yang disampaikan oleh Russel M.Knight (1987) dalam studi yang dilakukannya di kanada juga menyimpulkan hal yang sama bahwa seseorang wirausaha utamanya tidak di motivasi oleh Financial incentive, tetapi oleh keinginan untuk melepaskan diri dari lingkungan yang tidak sesuai, disamping itu guna menemukan arti baru bagi kehidupannya. Motivasi intrinsik yang tinggi dari siswa SMKN 12 Surabaya juga bisa dilihat dari antusiasme siswa ketika mengikuti setiap kegiatan kewirausahaan yang diadakan sekolah. Antusiasme siswa menunjukkan bahwa siswa memiliki ketertarikan besar terhadap kegiatan kewirausahaan, rasa ketertarikan terhadap kegiatan kewirausahaan tersebut diharapkan akan menumbuhkan minat berwirausaha dalam diri siswa

Berdasarkan teori dan hasil penelitian yang ada maka sekolah bisa melakukan berbagai langkah agar motivasi yang telah ada pada diri siswa bisa semakin ditumbuhkan dan terbina dengan baik yaitu dengan melibatkan seluruh siswa secara aktif kedalam kegiatan kewirausahaan seperti seminar dengan narasumber pengusaha atau pelaku bisnis, kegiatan yang diselenggarakan oleh bisnis center, di koperasi sekolah, mengikut sertakan siswa dalam kompetisi kewirausahaan seperti student company. Dengan keterlibatan siswa pada kegiatan tersebut diharapkan akan semakin memotivasi mereka untuk tertarik menjadi wirausaha dan menyadari bahwa berwirausaha merupakan salah satu pilihan pekerjaan yang perlu mereka pertimbangkan untuk dipilih jika mereka lulus nanti. Menginggat siswa SMK telah dipersiapkan dan dibekali dengan berbagai kompetensi keahlian yang mendukung untuk mereka bisa bekerja secara mandiri.

\section{Pengaruh Pengetahuan Kewirausahaan terhadap Minat Berwirausaha}

Pengetahuan kewirausahaan tidak berpengaruh signifikan terhadap minat berwirausaha.Hasil tersebut mempunyai makna bahwa peningkatan pengetahuan kewirausahaan tidak diikuti oleh minat untuk berwirausaha.

Temuan ini yang menunjukkan bahwa pengetahuan kewirausahaan tidak berpengaruh terhadap minat berwirausaha siswa seperti hasil penelitian dari Kuntowicaksono (2012) yang menunjukkan bahwa" tidak ada pengaruh secara parsial pengetahuan kewirausahaan terhadap minat berwirausaha siswa. Hal ini diperkuat dari hasil penelitian dari Aprilianty (2012) bahwa "seorang siswa akan mempunyai minat berwirauaha apabila siswa tahu secara benar tentang seluruh karakteristik dalam dunia usaha. Apabila siswa hanya 
memahami hanya sebagian dari ciri-ciri berwirausaha, maka akan cenderung manemui kegagalan karena siswa tidak mampu menganalisis secara komprehensif tentang faktor internal dan faktor eksternal yang mampu mendukung ke berhasilan usaha yang dijalankan. Temuan diatas bertolak belakang dengan penelitian yang dilakukan oleh Roxas (2008) bahwa mereka yang memiliki pengetahuan kewirausahaan terbukti dapat meningkatkan minat kewirausahaan seseorang.

Tingginya nilai pengetahuan kewirausahaan yang tidak diikuti oleh minat berwirausaha siswa SMKN 12 Surabaya disebabkan karena pengetahuan kewirausahaan yang diterima siswa sendiri selama ini hanya pada ranah pengetahuan teori (kognitif) saja sedangkan pengetahuan psikomotoriknya sangat kurang. Siswa terbatas mendegarkan keterangan guru, kemudian tidak betul-betul memahami materi yang diajarkan. Pengetahuan yang diberikan secara teori saja menyebabkan siswa mengalami kebosanan karena siswa menganggap pengetahuan kewirausahaan tidak menarik. Karena itu mereka cenderung lebih memprioritaskan pelajaran produktif mereka, hal ini disebabkan pelajaran produktif (kompetensi keahlian jurusan) tidak hanya memberikan pengetahuan secara teori tetapi juga pengetahuan secara praktek (psikomotorik). Sebagian dari siswa mendapat nilai yang tinggi pada mata pelajaran kewirausahaan, bukan karena mereka memahami pengetahuan yang diberikan tetapi karena saat ujian, para siswa hanya menghafalkan materi pelajaran. Setelah ujian selesai siswa lupa apa yang telah mereka pelajari.

Hal tersebut sesuai dengan pendapat Arifin (2011: 71) bahwa "dalam penelitian sering ditemui hasil belajar yang dicapai tampaknya baik, tetapi sebenarnya hasil belajar itu palsu. Peserta didik hanya dapat mengucapkan kata kata yang dihafalkan dari buku pelajaranya, tetapi mereka tidak dapat menggunakannya dalam situasi baru. Penguasaan matapelajaran seperti ini tidak lebih dari penguasaan beo, yang pada akhirnya peserta didik hanya memiliki pengetahuan yang bersifat informatif, belum tentu menjamin pemahaman dan pengertiannya untuk diaplikasikan dalam kehidupan". Akibatnya pengetahuan kewirausahaan yang diterima siswa menjadi tidak bermakna. Hal ini juga yang menyebabkan siswa tidak terdorong untuk mengaplikasikan ilmu yang mereka peroleh secara nyata. Menurut Rudy (2011) belajar akan lebih bermakna jika anak mengalami langsung apa yang dipelajarinya dengan mengaktifkan lebih banyak indera daripada hanya mendengarkan orang/guru menjelaskan. Pengalaman langsung tersebut bisa diperoleh siswa melalui pemberian pengetahuan secara praktek. Praktek merupakan upaya untuk memberi kesempatan kepada siswa mendapatkan pengalaman langsung dan memahami konsepkonsep teori yang telah diberikan. Kurangnya praktek atau pengaplikasian pengetahuan kewirausahaan secara teori kedalam kondisi nyata juga menyebabkan salah satu tujuan dari pembelajaran kewirausahaan yaitu mendorong lahirnya wirausaha-wirausaha baru tidak bisa diwujudkan. Kurang berfungsinya fasilitas pendukung seperti Bussines Center sebagai salah satu tempat untuk melakukan praktek kewirausahaan menyebabkan tidak maksimalnya pencapaian tujuan pembelajaran kewirausahaan sendiri yaitu mendorong lahirnya wirausaha-wirausaha baru

\section{Pengaruh Kepribadian terhadap Minat Berwirausaha}

Berdasarkan hasil penelitian mengenai pengaruh kepribadian terhadap minat berwirausaha menunjukkan bahwa kepribadian berpengaruh terhadap minat berwirauasaha. Implikasi dari penelitian ini adalah semakin baik kepribadian maka akan dapat meningkatkan minat berwirausaha. 
Temuan yang menunjukkan bahwa kepribadian berpengaruh terhadap minat berwirausaha siswa seperti hasil penelitian dari Lutfiandi dan Rahmanto (2011) bahwa kepribadian mempunyai pengaruh yang signifikan terhadap minat berwirausaha siswa. Hal senada juga diungkapkan oleh Othman, Mutalib, Ahman, dan Ismail (2000) dalam penelitiannya bahwa dimensi kepribadian bekorelasi positif dengan kecenderungan berwirausaha.

Berdasarkan jawaban tertinggi responden diketahui bahwa kepribadian siswa SMKN 12 Surabaya cukup baik. Mereka memiliki daya kreatif kreativitas yang tinggi dalam dirinya, ini dapat dilihat dari nilai rata-rata tertinggi jawaban responden untuk indikator kreativitas sebesar 4,36. Kreativitas tersebut ditunjukkan dari kemampuan menghasilkan dan mencoba ide-ide baru, khususnya berkaitan dengan kemampuan mereka dalam membuat hasil karya (produk) yang berhubungan dengan kompetensi jurusannya. Hal ini diperlihatkan siswa ketika melaksanakan praktek penjualan mereka mampu untuk menjual hasil karya yang mereka buat sendiri dan pada pelaksanaan pameran hasil karya siswa.

Seorang wirausaha membutuhkan kepribadian yang baik agar dapat mendukung minat berwirausaha seperti mampu mandiri, mampu mengambil keputusan untuk dirinya sendiri, memiliki rasa percaya diri, seorang yang efisien dalam menggunakan waktu, kreatif, berani mengambil resiko, tabah dalam menghadapi cobaan, ulet, memiliki moralitas yang baik, dan memiliki jiwa kepemimpinan.Dengan kepribadian yang baik akan tercipta kepribadian yang produktif yaitu seseorang yang selalu memberi kontribusi positif bagi lingkungannya, inovatif, bertanggung jawab dan responsif dalam berhubungan dengan orang lain, mandiri, kritis, obyektif.

Menurut Aprilianty (2012) dalam penelitian menyatakan bahwa berbagai pihak perlu membantu siswa agar dapat menumbuhkan dan membangun potensi diri siswa. Sebab yang mendukung terbentuknya sumber daya manusia yang mampu mengelola usaha adalah kepribadian wirausaha seperti percaya diri, kreatif, berani mengambil resiko, berorientasi pada hasil, kepemimpinan, dan kerja keras perlu ditanamkan pada diri siswa. Sehingga siswa yang memiliki kepribadian tangguh semakin banyak. Jika semakin banyak yang memiliki dan mempunyai potensi kepribadian wirausaha, semakin banyak pula yang berminat berwirausaha dan siap menjalani proses kewirausahaan

Berdasarkan hasil penelitian dan teori yang ada, sekolah dan guru khususnya guru kewirausahaan untuk memperkuat kepribadian siswa. Karena dalam pembelajaran kewirausahaan terdapat materi yang mendukung untuk itu yaitu materi karakateristik wirausaha maka kesempatan bagi guru untuk bisa menanamkan kepribadian siswa untuk memiliki percaya diri, kreatif, berani mengambil resiko, berorientasi pada hasil, kepemimpinan, dan kerja keras sebagai bekal bagi mereka untuk terjun ke masyarakat.

\section{Pengaruh Motivasi Intrinsik, Pengetahuan Kewirausahaan, dan Kepribadian terhadap Minat Berwirausaha}

Hasil penelitian menunjukkan bahwa motivasi intrinsik, pengetahuan kewirausahaan, dan kepribadian secara simultan berpengaruh terhadap peningkatan minat berwirausaha siswa SMKN 12 Surabaya. Implikasi dari temuan tersebut adalah semakin bagus motivasi intrinsik, pengetahuan kewirausahaan, dan kepribadian maka akan semakin tinggi minat berwirausaha. Sebaliknya semakin rendah motivasi intrinsik, pengetahuan kewirausahaan, dan kepribadian maka akan semakin rendah minat berwirausaha.

Hasil penelitian ini didukung penelitian Limbong (2010) menunjukkan bahwa terdapat pengaruh yang positif dan signifikan antara sikap mandiri, pengetahuan kewirausa- 
haan dan motivasi berwirausaha terhadap minat berwirausaha. Begitu juga penelitian yang dilakukan oleh Fitriani (2009) menunjukkan bahwa kepribadian mempengaruhi minat berwirausaha secara signifikan. Hasil penelitian ini juga semakin diperkuat oleh teori dari McClelland (dalam utami,2007:21) bahwa ada tiga faktor intern yang mempengaruhi minat seseorang dalam berwirausaha yaitu motivasi, pengalaman atau pengetahuan, dan kepribadian. Dengan motivasi yang tinggi, penguasaan pengetahuan yang baik, dan kepribadian yang menarik akan dapat menumbuhkan minat berwirausaha siswa.

Berdasarkan hasil temuan diketahui bahwa siswa SMKN 12 Surabaya memiliki minat untuk berwirausaha, hal ini terlihat dari nilai rata-rata jawaban tertinggi responden sebesar 4,15.Minat berwirausaha siswa dapat ditumbuhkan dengan mengikutrsertakan siswa kedalam berbagai kegiatan seperti sebuah program kompetisi student company. Sebuah ajang kompetisi bagi siswa untuk belajar sekaligus berkompetisi mendirikan usaha. Dalam program ini siswa diajarkan bagaimana mereka mendirikan sebuah usaha sekaligus menjalankannya. Lewat program]am student company ini siswa diharapkan memperoleh pengetahuan dan pengalaman langsung yang dapat memotivasi mereka untuk minat berwirausaha sekaligus diharapkan dapat merubah pola pikir sebagian dari siswa bahwa profesi berwirausaha bukan merupakan profesi yang dapat dipakai sebagai jaminan hidup.

\section{KESIMPULAN}

Kesimpulan dari pembahasan penelitian ini adalah sebagai berikut:

1. Motivasi intrinsik, pengetahuan kewirausahaan, dan kepribadian secarasimultan berpengaruh signifikan terhadap minat berwirausaha. Motivasi intrinsik yang tinggi, pengetahuan kewirausahaan yang baik, dan kepribadian yang bk akan semakin meningkatkan minat berwirauasaha.

2. Motivasi intrinsik secara parsial berpengaruh signifikan terhadap minat berwirausaha siswa dan disimpulkan semakin baik motivasi intrinsik akan berpengaruh terhadap peningkatan minat berwirausaha.

3. Pengetahuan kewirausahaan secara parsial tidak berpengaruah signifikan terhadap minat berwirausaha sehingga disimpulkan bahwa pengetahuan kewirausahaan baik tidak diikuti dengan peningkatan minat berwirausaha.

4. Kepribadian secara parsial berpengaruh signifikan terhadap minat berwirausaha sehingg disimpulkan bahwa semakin baik kepribadian akan berpengaruh terhadap peningakatan minat berwirausaha siswa.

Saran yang dapat diberikan berdasarkan hasil penelitian ini adalah:

1. Motivasi yang telah ada dalam diri siswa hendaknya bisa dipertahankan. Salah satu cara yang bisa dilakukan dalah dengan seringnya melibatkan mereka ke dalam satu bentuk kegiatan yang dapat semakin membangkit motivasi dalam diri mereka misalnya dengan sering mendatangkan pelaku-pelaku bisnis untuk bisa berbagi pengalaman tentang bagaimana mereka memulai usaha; melibatkan mereka dalam setiap kegiatan kewirausahaan sekolah; melakukan pameran atas hasil karya siswa dalam sebuah event-evet tertentu.

2. Disarankan pemberian pengetahuan kewirausahaan yang dilakukan disekolah tidak hanya pada ranah teori seperti yang telah berlangsung selama ini tetapi siswa juga perlu diajarkan bagaimana mengaplikasikan teori yang dia terima secara nyata. Hal 
tersebut bisa dilakukan dengan mefungsikan kembali bisnis center sebagai wadah praktek kerja bagi siswa di sekolah dan mengajak siswa untuk melakukan praktek kewirausahaan dengan memasarkan produk yang merupakan produk unggulan dari masing-masing jurusan. Dengan demikian pengetahuan kewirausahaan yang diterima akan jauh lebih bermakna karena mereka secara langsung mengalami sendiri.

3. Guru disarankan mampu menanamkan nilai-nilai potensi kepribadian yang positf dalam diri siswa ,sehingga guru tidak hanya berperan mentransfer ilmu pengetahuan saja tetapi juga berperan membentuk dan memperkuat nilai-nilai kepribadian yang positif dengan cara mengintegrasikan nilai-nilai percaya diri, kreativitas, keberanian mengambil resiko, kepemimpinan dan kerja keras dalam setiap mata pelajaran di sekolah. Menginggat potensi kepribadian juga memegang peran penting dalam menentukan kesuksesan siswa nantinya.

4. Guru disarankan bisa merubah persepsi siswa bahwa wirausaha merupakan pekerjaan yang tidak bisa memberikan jaminan hidup dan penuh resiko, sehingga mereka cenderung untuk memilih bekerja pada orang lain. Hal ini bisa dilakukan dengan melibatkan mereka ke dalam sebuah kompetensi kewirausahaan salah satunya seperti ajang kompetisi student company, agar siswa melalui ajang kompetisi tersebut akan belajar secara langsung bagaimana cara mendirikan dan menjalankan usaha dari orang-orang yang kompeten dibidangnya, juga bisa lebih menyadari bahwa ada banyak hal menarik yang bisa mereka dapatkan dengan menjadi wirausaha. Sehingga diharapkan terjadi perubahan pola pikir dari menjadi buruh/pegawai menjadi wirausahawan.

\section{DAFTAR PUSTAKA}

Aprilianty. Eka. 2012. Pengaruh Potensi Kepribadian Wirausaha, Pengetahuan, dan Lingkungan Terhadap Minat Berwirausaha Siswa SMK Rumpun Pertanian di Daerah Istimewa Yogyakarta.Universitas Negeri Yogyakarta.

Arifin, Zainal. 2011. Evaluasi pembelajaran. Bandung: Remaja Rosdakarya

Ciputra. 2011. Quantum Leaps 2. Jakarta: PT Gramedia.

Mahesa. Aditya Dion dan Edy Rahardja.2012.Analisis Faktor-faktor Motivasi yang Mempengaruhi Minat Berwirausaha.Jurnal Of Management Vol.1,Nomor 1, Tahun 2012.

Djaali. 2006. Psikologi Pendidikan. Jakarta : Bumi Aksara

Fitriany, Diah.2009.Pengaruh Kepribadian dan Kecemasan akan Sempitnya Lapangan Pekerjaan terhadap Minat Berwirausaha Mahasiswa.Yogyakarta:Fakultas Ekonomi Universitas Ahmad Dahlan Yogyakarta.

Knight, Russel M. (1987). Journal of Product Innovation Management Volume 4, Issue 4, pages 284-297, December 1987

Kuntowicaksono.2012.Pengaruh Pengetahuan Wirausaha dan Kemampuan Memecahkan Masalah Wirausaha Terhadap Minat Berwirausaha Siswa Sekolah Menengah Kejuruan. Joernal Economic of Education Vol 1(1). Semarang:Prodi Pendidikan Ekonomi Pascasarjana Universitas Negeri Semarang. 
Kurniawan, Haris. 2012. Motivasi Berwirausaha. http://wawanhariskurnia.blogspot. com/2012/12/motivasi-berwirausaha.html/diakses pada tanggal 25 Juni 2012

Limbong,Benri.2010.Pengaruh Antara Sikap Mandiri, Pengetahuan Kewirausahaan dan Motivasi Berwirausaha terhadap Minat Berwirausaha Terhadap Minat Berwirausaha Siswa-Siswi SMK di Kota Medan. Sekolah Pasca Sarjana Universitas Sumatra Utara.

Lutfiandi,Ridwan dan M.Ikhwan Rahmanto. 2011. Analisis Peran Pendidikan Kewirausahaan, Kepribadian, dan Lingkungan terhadap Minat Siswa SMK untuk Berwirausaha di Kota Bekasi.Jurnal Agribisnis dan Pengembangan Wilayah Vol.3 No.1 Desember 2011.

Othman, Fazilah Mohd, Rozita Abdul Mutalib, Zalinah Ahmad, dan nur Syakiran Akmal Ismail. 2000. Relationship Between Personality and Entrepreneurial Inclination Among University Students, The International Journal of Interdisciplinary Social Sciences, 2(4), pp.277-288.

Pink,Daniel H.2009.Drive:The Suprissing Truth About What Motivates Us.Canongate Books Limited.

Roxas, Hernan Banjo. 2008. Entrepreneurial Knowledge and its Effects on Entrepreneurial Intentions: A Longitudinal Study of Selected Senior Business Students in the Philippines. Asia-Pacific social science review, vol. 8, no. 2, pp. 61-77, De La Salle University, Manila, Philippines.

Rudy. 2011. Pembelajaran Bermakna (Meaningfull Learning). http://rudy-unesa.blogspot. com/2011/02/pembelajaran-bermakna-meaningfull.html. tanggal diunduh. 9 Mei 2013

Segal, Gerry, Borgia and Jerry Schoenfeld. 2005. The Motivation To Become An Entrepreneur. International Journal of Entrepreneurial Behavior \& Researc. Vol. 11 No 1. Emerald Group Publishing Limited. USA.

Shaleh, Abdul Rahman dan Wahab, Muhbid Abdul. 2004. Psikologi Suatu Pengantar Dalam Persepsi Islam : Jakarta.

Sugiyono. 2008. Metode Penelitian Kuantitatif Kualitatif Dan R\&D.Bandung : Alfabeta.

Wibowo, Agus. 2011. Pendidikan Kewirausahaan. Yogyakarta: Pustaka Pelajar 